\title{
Retraction Note: HGF and TGF $\beta 1$ differently influenced Wwox regulatory function on Twist program for mesenchymal-epithelial transition in bone metastatic versus parental breast carcinoma cells
}

\author{
Paola Bendinelli ${ }^{1 \dagger}$, Paola Maroni ${ }^{2 \dagger}$, Emanuela Matteucci ${ }^{1}$ and Maria Alfonsina Desiderio ${ }^{1 *}$
}

Retraction note to: Mol Cancer 14, 112 (2015)

https://doi.org/10.1186/s12943-015-0389-y

The Editor-in-Chief has retracted this article [1] following an investigation by the Università degli Studi di Milano. The investigation found that both Figs. 2 and 3 have key problems of different types of manipulations of the vinculin WB used as loading control. In Fig. 2, the vinculin protein bands have been used in other publications from the same groups [2-4], while band rotation seems to have been performed in Fig. 3 to clone vinculin bands. The results of this study are thus unreliable.

The authors do not agree to this retraction.

\section{Author details}

'Dipartimento di Scienze Biomediche per la Salute, Molecular Pathology Laboratory, Università degli Studi di Milano, Milano, Italy. ${ }^{2}$ Istituto Ortopedico Galeazzi, IRCCS, Milano, Italy.

Published online: 15 August 2020

\section{References}

1. Bendinelli P, Maroni P, Matteucci E, et al. HGF and TGF $\beta 1$ differently influenced Wwox regulatory function on Twist program for mesenchymalepithelial transition in bone metastatic versus parental breast carcinoma cells. Mol Cancer. 2015;14:112 https://doi.org/10.1186/s12943-015-0389-y.

The original article can be found online at https://doi.org/10.1186/s12943015-0389-y.

*Correspondence: a.desiderio@unimi.it

${ }^{\dagger}$ Paola Bendinelli and Paola Maroni contributed equally to this work.

'Dipartimento di Scienze Biomediche per la Salute, Molecular Pathology

Laboratory, Università degli Studi di Milano, Milano, Italy
2. Maroni $\mathrm{P}$, Bendinelli $\mathrm{P}$, Matteucci $\mathrm{E}$, et al. Osteolytic bone metastasis is hampered by impinging on the interplay among autophagy, anoikis and ossification. Cell Death Dis. 2014;5:e1005 https://doi.org/10.1038/cddis.2013. 465.

3. Bendinelli P, Maroni P, Matteucci E, et al. Epigenetic regulation of HGF/Met receptor axis is critical for the outgrowth of bone metastasis from breast carcinoma. Cell Death Dis. 2017;8:e2578 https://doi.org/10.1038/cddis.2016. 403.

4. Ridolfi E, Matteucci E, Maroni P, et al. Inhibitory effect of HGF on invasiveness of aggressive MDA-MB231 breast carcinoma cells, and role of HDACs. Br J Cancer. 2008;99:1623-34 https://doi.org/10.1038/sj.bjc.6604726.

(c) The Author(s). 2020 Open Access This article is licensed under a Creative Commons Attribution 4.0 International License, which permits use, sharing, adaptation, distribution and reproduction in any medium or format, as long as you give appropriate credit to the original author(s) and the source, provide a link to the Creative Commons licence, and indicate if changes were made. The images or other third party material in this article are included in the article's Creative Commons licence, unless indicated otherwise in a credit line to the material. If material is not included in the article's Creative Commons licence and your intended use is not permitted by statutory regulation or exceeds the permitted use, you will need to obtain permission directly from the copyright holder. To view a copy of this licence, visit http://creativecommons.org/licenses/by/4.0/. The Creative Commons Public Domain Dedication waiver (http://creativecommons.org/publicdomain/zero/1.0/) applies to the data made available in this article, unless otherwise stated in a credit line to the data. 